\title{
Sedimentology and Sequence Stratigraphy of the Eocene Nanka Formation (Ameki Group): An Evaluation of Ogbunike Reference Locality in Anambra Basin, South-Eastern Nigeria.
}

\author{
Chiaghanam O.I. ${ }^{1^{*}}$, Chiadikobi, K.C. ${ }^{2}$, Ikegwuonwu, O.N. $^{3}$, Omoboriowo, \\ A.O. ${ }^{4}$, Onyemesili, O.C. ${ }^{5}$, Yikarebogha, Y. ${ }^{6}$ \\ 1,2,5 Department of Geology, Anambra State University, Uli \\ ${ }^{3}$ Department of Geology, University of Nigeria, Nsukka \\ ${ }^{4}$ Department of Earth Sciences, Federal University of Petroleum Resources, Effurun. \\ ${ }^{6}$ Department of Petroleum Resources, Benin City
}

\begin{abstract}
Sedimentology and Sequence stratigraphic study of Eocene Nanka Formation, situated at a reference locality in Ogbunike south-eastern Nigeria,showed a section made up of ironstone/sandstone and shale, sandstone, sandstone/siltstone and interstratified calcareous clay and shale facies.Palynological analyses on Facie A shows that the presence of monoporitesannulatus , proxapertitescursus/ operculatus, schizosporisparvus, Homotryblium spp.anddiphysescolligerum suggest a paleoenvironment in a continental shelf,while age diagnosting index palynomorphs species present,suggest a middle Eocene age for the section.The sieve and paleocurrent analyses carried out on Facies $C$ shows fluvial dominated environment.Sequence stratigraphic analyses of the area indicate a late highstand systems tract and lowstand systems tract,with a type II sequence boundary.
\end{abstract}

Keywords: Sedimentology,Sequence stratigraphy,Anambra Basin,Nanka Formation and Eocene.

\section{Introduction}

This study examines part of the sedimentary units of the Eocene Nanka Formation of Anambra Basin exposed at (lat. $6^{\circ} 10^{\prime} 52.4^{\prime \prime} \mathrm{N}$ and long. $6^{\circ} 51^{\prime} 54.3^{\prime \prime}$ E) Ogbunike near Old Onitsha toll gate, along OnitshaEnugu expressway in Anambra State, Southeastern Nigeria.See Fig, 1. Reyment, (1965), Nwajide, (1979, 1980, 2006).Nwajide and Reijers (1996), Umeji,( 2003) and Chiaghanam, (2008) have studied the Nanka Formation with respect to their lithostratgrphy, age relations, sequence stratigraphy, depositional environment, reservoir properties and clastic sedimentary structures.

This study has integrated lithofacies, palynology, paleocurrent and sequence stratigraphy in the interpretation of EoceneNankaFormation in the Anambra Basin, Southeastern Nigeria.

This paper attempts to re-evaluate the sedimentology, palynology and stratigraphic architecture of the Nanka Formation, using Ogbunikereference locality as a model that may be used as a regional framework for a basinwide predictions.

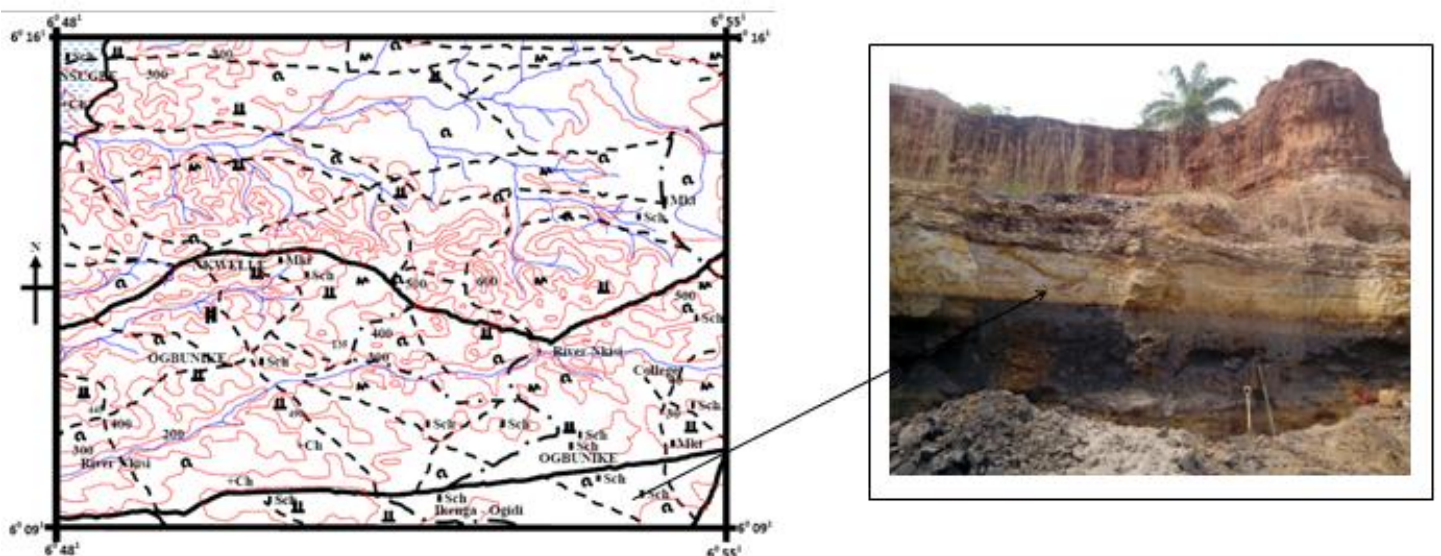

Fig 1: Map of the Study Area with the photograph inserted

\section{Regional Tectonic And Stratigraphic Setting-}

Anambra Basin developed as a result of the Santonianevents which greatly affected the Benue through terminating sedimentation in the Abakaliki Basin. However, sedimentation in Southern Nigeria which began in the early cretaceous was facilitated by the breakup of the African and South American continents leading to the 
Sedimentology and Sequence Stratigraphy of the Eocene Nanka Formation (Ameki Group): ...

formation of the Benue Trough (Benkhelil, 1989). Sedimentation in the trough was controlled by three major tectonic phases, giving rise to three successive depocenters (murat, 1972: Oboh-Ikuenobe et al, 2005, Nwachukwu et, al, 2011).

The First phase (Albian- Santonian) featured the deposition of the Asu River Group, Eze-aku and AwguFormations within the Abakaliki-Benue Trough which was flanked to the east by the Anambra platform and to the Southwest by the Ikpe platform (Nwachukwu et, al. 2011).

The second phase (Campanian- Eocene) was characterized by compressive movement along the NE-SW axis which resulted in the folding and uplift of the trough into an anticlinorium. This forced the Anambra platform to subside and the depocenter to shift South-Westwards to the newly formed Anambra Basin and the Afipko syncline on the other side of the anticlinorium in the southeast. The deposition of the Nkporo Group, MamuFormation, Ajali Sandstone, NsukkaFormation, Imo Formation and the Ameki Group followed (Nwachukwuet, al, 2011). The third phase commenced towards the end of Eocene and was characterized by the structural inversion of the Abakaliki region, further shifting the depocenter down dip (southwards) to form the Niger Delta basin(obiet, al, 2001, Nwachukwu et, al, 201). see table 1

The lithology of the formation (Nanka Formation) of the study area, as typified in the type locality,taken along agully between Nanka and Agulu, is overwhelminglyloosed;flaser bedded to medium sand, with a few mudrock breaks. The sand consists of sub-rounded to sub-angular grains and has an average of 5\% clay content which makes it texturally submature. It is however compositionally high mature on account of the absence of feldspars and the dominance of the ultrastableheavy mineral suit-Zircon, tourmaline and rutile. Kyanite and staurolite constitute the balance of the non-opaque heavies, and point to metamorphic parents rocks as the main provenance material. The area is generally of calcareous clays and silts with thin shelly limestone, rich in foraminifera. Nwajide(2013).

Table 1: Lithostratigraphic Framework of Anambra Basin (after Nwajide, 1990)

\begin{tabular}{|c|c|c|c|}
\hline \multicolumn{2}{|l|}{ AGE } & ABAKALIKI-ANAMBRA BASIN & AFIKPO BASIN \\
\hline $30 \mathrm{my}$ & Oligocene & Ogwashi-Asaba Formation & Ogwashi-Asaba \\
\hline $54.9 \mathrm{my}$ & Eocene & Ameki/NankaFormation/Nsugbe Sandsto & Ameki Formation \\
\hline $60 \mathrm{my}$ & Paleocene & Imo Formation & Imo Formation \\
\hline & \multirow[b]{2}{*}{ Maastrichtian } & Nsukka Formation & Nsukka \\
\hline $73 \mathrm{my}$ & & Ajalli Sandstone & Ajalli Sandstone \\
\hline 83 my & CampanianNkpord & / Owelli Formation/Enugu Shale Nkpor & \multirow[t]{3}{*}{ o Shale/Afikpo Sandstone } \\
\hline $87.5 \mathrm{my}$ & Santonian & Non-deposition & \\
\hline $88.5 \mathrm{my}$ & Coniacian & wgu Group (Agbani Sandstone/Awgu Shale) & \\
\hline \multirow{3}{*}{$\begin{array}{l}93 \text { my } \\
100 \text { my }\end{array}$} & Turonian & Ezeaku Group) & \multirow{2}{*}{$\begin{array}{l}\text { Ezeaku Group (inclAmaseri } \\
\text { Sandstone) }\end{array}$} \\
\hline & Cenomanian- Albian & Asu River Group & \\
\hline & $\begin{array}{l}\text { Aptian } \\
\text { BaremianUnamed } \\
\text { Hauterivian }\end{array}$ & \multicolumn{2}{|l|}{ Units } \\
\hline & Precambrian & \multicolumn{2}{|l|}{ Basement Complex } \\
\hline
\end{tabular}

Table 1: Lithostratigraphic Framework of Anambra Basin (after Nwajide, 1990) 


\section{Methods And Materials}

The slope of the Ogbunike area provides complete and easy access to the outcrop of Nanka Formation in the study area (see fig. 2).

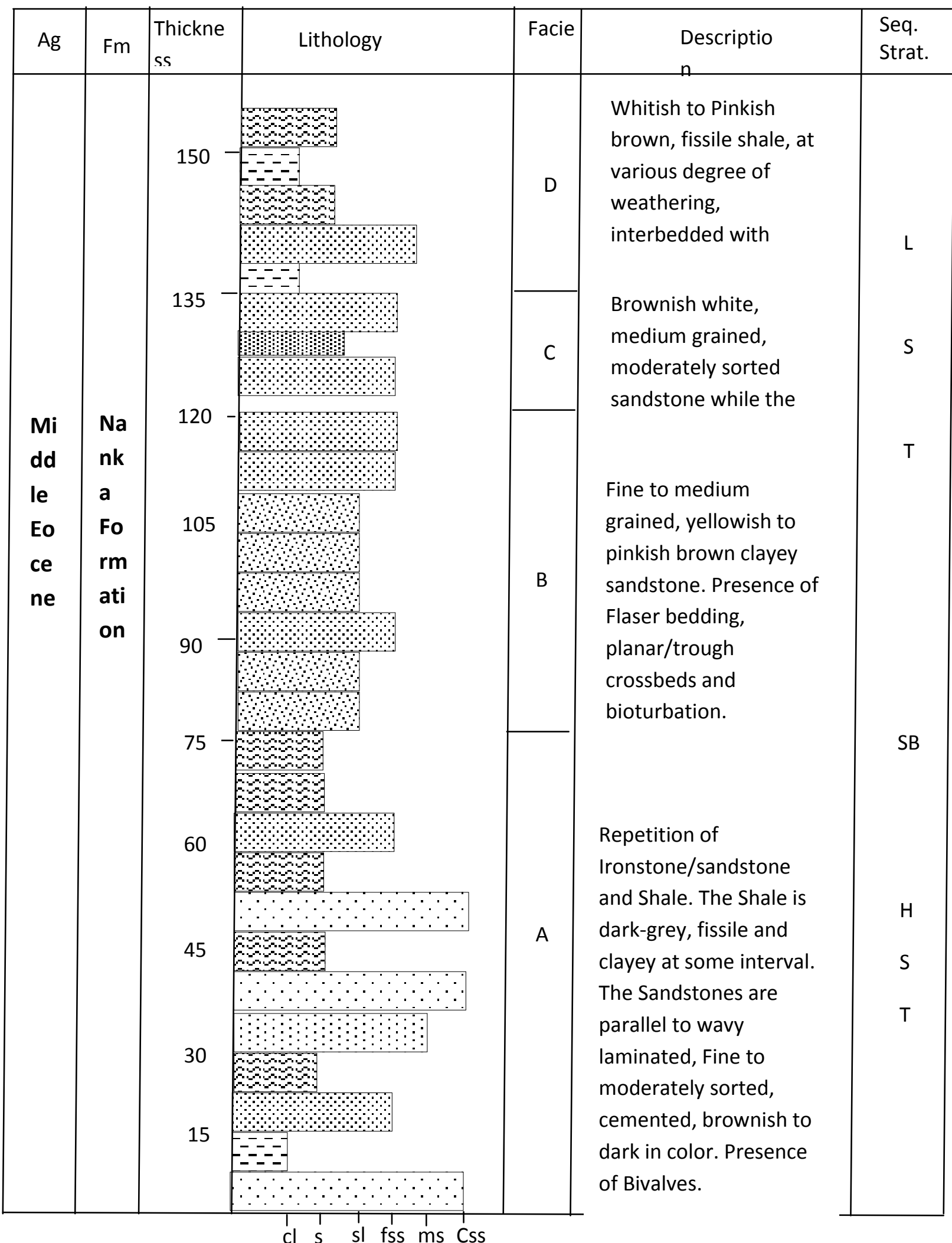

Fig 2: Logged Outcrop Section showing facies and sequence stratigraphy 
Fresh samples of shales recovered from units $21,23,25$ and 28 of the outcrop were analyzed for palynomorphs using the maceration technique. Each sample was digested for 30 minutes in $37 \%$ hydrochloric acid to remove traces of carbonate and 72 hours in $48 \%$ hydrofluoric acid to remove silicate. The extracts were sieve-washed with water through 10 microns nylon mesh, oxidized for 30 minutes in $70 \% \mathrm{HNO}_{3}$ and 5 minutes in Schulz solution to render the fossils translucent for transmitted light microscopy. The oxidized residues were rinsed in $2 \% \mathrm{KOH}$ solution to neutralize the acid.Swirling treatment was undertaken in order to get rid of the resistant coarse inorganic mineral particles. The residues were stained with Safranin-0 to increase the contrast. The orientation of directional sedimentary structure (cross beds) was determined with a silver compass by taking measurements from individual beds that are cross bedded, following Sam Boggs, Jr. (2006) model. Sequence stratigraphic interpretations followed the method of Van Wagoner et, al. (1988).

\section{Result And Interpretations}

Ironstone/sandstone and shale facies (A) -This forms the base of the outcrop. It is made of repetitive or cyclic deposition of ironstone/sandstone and shale at an almost equal proportion. The shales are dark -grey in colour, fissile , and clayey in some places. The sandstone intervals are parallelto wavy laminated, fine to medium grained, moderately sorted and occasionally highly compacted/cemented. They are generally brownish to dark in colour, highly fossilferrous as evidenced by the presence of bivalves that occurred in coquina form. Large assemblage of palynomorphs were recovered from the shale intervals (unit 21, 23, 25, 28) which includes verrucato sporitesus mens is, laevigatos poritesovatus, psiltricolporites operculatus, Spinizonocolpites echinatus,proxapertitescursus, retistephanocolpiteswilliamsi,psilatricolporites

sp., Psiltricolporitescrassus, psitricolporitesrotundos, Echitriporitestrianguliformis,

Achilleodiniumbiformoides, Homotryblium spp., among other (Fig 3 and table 2). The presences of shale are an indication of marine influence environment, but are tidal dominated.

Table 2: The occurrence and distribution of Palynomorphs species in the analyzed section.

\begin{tabular}{|c|c|c|c|c|}
\hline$\underbrace{\text { Sample No. }}_{\text {Palynomorphs species }}$ & UNIT 21 & UNIT 23 & UNIT 25 & $\begin{array}{l}\text { UNIT } \\
28\end{array}$ \\
\hline TERRESTRIAL SPECIES & + & & & \\
\hline \multicolumn{5}{|l|}{ Spores } \\
\hline Schizosporisparvus & - & 4 & - & 1 \\
\hline Cyathidites minor & - & 2 & 3 & 2 \\
\hline Leiotriletesadriennis & 8 & 4 & 2 & 1 \\
\hline Leiotriletesmaxoides & 2 & - & - & - \\
\hline Verrucatosporitesusmensis & 7 & 12 & 5 & 3 \\
\hline Laevigatosporitesovatus & 17 & 14 & 9 & 10 \\
\hline Cicatricosisporitesdorogensis & - & 1 & - & - \\
\hline Polypodiaceoisporites sp. & - & - & - & - \\
\hline \multicolumn{5}{|l|}{ Pollen } \\
\hline Psiltricolporitesoperculatus & 4 & 8 & 2 & 1 \\
\hline Spinizonocolpitesechinatus & 6 & 2 & 1 & 2 \\
\hline Proxapertitesoperculatus & - & - & - & - \\
\hline Proxapertitescursus & 7 & 3 & 2 & 1 \\
\hline Retitricolporitesirregulari & 3 & 1 & - & - \\
\hline Retistephanocolpiteswilliamsi & 4 & 2 & 1 & 1 \\
\hline Pachydermitesdiederixi & 2 & - & - & - \\
\hline Ctenolophoniditescostatus & - & 4 & - & - \\
\hline Tricolpiteshians & 1 & 2 & 3 & - \\
\hline Striatopolliscatatumbus & - & 1 & - & - \\
\hline Monocolpitesmarginatus & 2 & - & - & - \\
\hline Monoporitesannulatus & 2 & 3 & 1 & 1 \\
\hline Psilatricolporites sp. & 3 & 2 & 5 & 2 \\
\hline Psiltricolporitescrassus & 4 & 2 & 2 & 1 \\
\hline Inaperturopollenites sp. & - & 1 & - & - \\
\hline Retibrevitricolpitestriangulatus & 3 & 2 & 1 & 2 \\
\hline Psilatriporitesrotundus & 4 & 3 & 1 & 1 \\
\hline Echitriporitestrianguliformis & - & 4 & - & - \\
\hline Psilastephanocolporites sp. & - & 2 & 2 & - \\
\hline Echitricolporitesspinosus & - & 1 & - & - \\
\hline Anacolocidites cf. luteoidies & - & - & - & 1 \\
\hline Brevicolporites $(P)$ molinae & - & - & - & 1 \\
\hline Scabratriporitesannulatus & 2 & - & - & - \\
\hline
\end{tabular}




\begin{tabular}{|l|l|l|l|l|}
\hline Bombacidites sp. & - & 1 & - & - \\
\hline MARINE SPECIES & & & & \\
\hline Dinoflagellate cysts & & & & \\
\hline Coroniferaoceanica & - & 1 & - & - \\
\hline Hafniasphaeraseptata & - & 1 & - & - \\
\hline Achilleodiniumbiformoides & - & 2 & - & - \\
\hline Diphyescolligerum & - & 1 & - & - \\
\hline Homotryblium spp. & - & 2 & - & - \\
\hline Cordosphaeridiuminordes & - & - & - & - \\
\hline Spiniferiteshyperacanthus & - & - & - & - \\
\hline
\end{tabular}
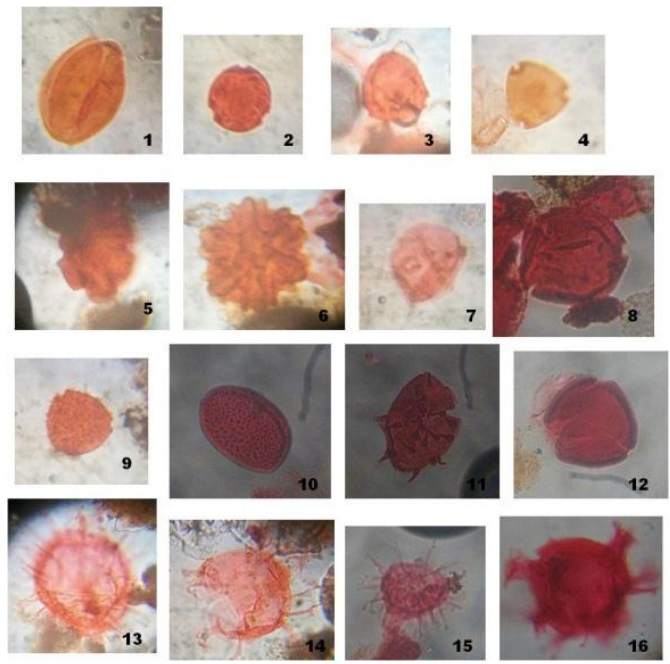

Fig. 3: Micrographs of some palynomorphs recovered from the analyzed samples.

Magnifications nos. 13 and 14 (X 100 oil immersion), others (X 40)

$\begin{array}{ll}\text { 1. } & \text { Schizosporisparvus } \\ \text { 2. } & \text { Scabratriporitesannulatus } \\ \text { 3. } & \text { Psilatricolporitesoperculatus } \\ \text { 4. } & \text { Psilatriporitesrotundus } \\ \text { 5. } & \text { Retistephanocolpiteswilliamsi } \\ \text { 6. } & \text { Ctenolophoniditescostatus } \\ \text { 7. } & \text { Monoporitesannulatus } \\ \text { 8. } & \text { Pachydermitesdiederixi }\end{array}$

9.Echitriporitestrianguliformis

10. Proxapertitescursus

11.Spinizonocolpitesechinatus

12. Psilatricolporitescrassus

13. Coroniferaoceanica

14. Hafniasphaeraseptata

15. Diphyescolligerum

16.Achilleodiniumbiformoides

Sandstone facies (B) - The interval is fine to medium grained, clayey, yellowish to pinkish brown sandstone. The sandstone isparallel laminated, friable and areeasily susceptible to erosion. The main characteristicsedimentary structures are flaser bedding, planar/ trough crossbeds with intervening mud drapes. There are also presence of reactivation surface and ironstains. The fossil assemblage'spresentfacies includesskolithus, ophiomorpha, with bioturbationsat various intervals.Paleocurrent analysis was carried at on the crossbedded units. The results as indicated from the rose diagram shows that the studied area is characterized by a unimodalpaleaocurrent pattern which indicate a fluvial environment. The Mean Vector Azimuth (MVA), Variance and Vector Strength were derived based on Steinmetz, (1962). See tables 3a, 3b, 3c and $3 \mathrm{~d}$.

Table 3a: Paleocurrent Parameters for Crossbed 0

\begin{tabular}{|l|l|l|l|l|l|l|l|l|}
\hline 1 & 2 & 3 & 4 & 5 & 6 & 7 & 8 & 9 \\
\hline Azimuth (A) & $\begin{array}{l}\text { Dip } \\
\text { (D) }\end{array}$ & Sine A & Cos A & Cos D & $\begin{array}{l}5 \times 4 \\
\text { B }\end{array}$ & $\begin{array}{l}5 \times 3 \\
\text { a }\end{array}$ & $\begin{array}{l}\text { Sine D } \\
\text { C }\end{array}$ & $\left(\mathrm{A}_{\mathbf{I}^{-}}\right.$A) ${ }^{2}$ \\
\hline 74 & 28 & 0.9613 & 0.2756 & 0.8829 & 0.2433 & 0.8487 & 0.4695 & 40.83 \\
\hline 68 & 18 & 0.9272 & 0.3746 & 0.9511 & 0.3563 & 0.8818 & 0.3090 & 153.51 \\
\hline 52 & 20 & 0.7880 & 0.6157 & 0.9397 & 0.5786 & 0.7405 & 0.3420 & 806.56 \\
\hline 80 & 16 & 0.9848 & 0.1736 & 0.9613 & 0.1669 & 0.9466 & 0.2756 & 0.15 \\
\hline 82 & 14 & 0.9903 & 0.1392 & 0.9703 & 0.1351 & 0.9609 & 0.2419 & 2.59 \\
\hline 84 & 17 & 0.9945 & 0.1045 & 0.9563 & 0.0999 & 0.9510 & 0.2924 & 13.03 \\
\hline
\end{tabular}


Sedimentology and Sequence Stratigraphy of the Eocene Nanka Formation (Ameki Group): ...

\begin{tabular}{|l|l|l|l|l|l|l|l|l|}
\hline 70 & 12 & 0.9397 & 0.3420 & 0.9781 & 0.3345 & 0.9191 & 0.2079 & 107.95 \\
\hline 82 & 20 & 0.9903 & 0.1392 & 0.9397 & 0.1308 & 0.9306 & 0.3420 & 2.59 \\
\hline 67 & 24 & 0.9205 & 0.3907 & 0.9135 & 0.3569 & 0.8409 & 0.4067 & 179.29 \\
\hline 94 & 28 & 0.9976 & -0.0698 & 0.8829 & -0.0616 & 0.8807 & 0.4695 & 185.23 \\
\hline 116 & 20 & 0.8988 & -0.4384 & 0.7397 & -0.412 & 0.6648 & 0.3420 & 1268.07 \\
\hline 110 & 12 & 0.9397 & -0.3420 & 0.9781 & -0.3345 & 0.9191 & 0.2079 & 876.75 \\
\hline 80 & 17 & 0.9848 & 0.1736 & 0.9563 & 0.166 & 0.9418 & 0.2924 & 0.15 \\
\hline 76 & 15 & 0.9703 & 0.2419 & 0.9659 & 0.2337 & 0.9372 & 0.2588 & 19.27 \\
\hline 73 & 7 & 0.9563 & 0.2924 & 0.9925 & 0.2902 & 0.9491 & 0.1219 & 54.61 \\
\hline Totals & & 14.2441 & 2.4128 & 14.2083 & 2.2841 & 13.3128 & 4.5795 & 3710.6 \\
\hline (Total) $^{2}$ & & 202.8934 & 5.8216 & 201.8758 & 5.2171 & 177.2306 & 20.9718 & 13768419.5 \\
\hline
\end{tabular}

Table 3b: Paleocurrent Parameters for Crossbed 1

\begin{tabular}{|c|c|c|c|c|c|c|c|c|}
\hline 1 & 2 & 3 & 4 & 5 & 6 & 7 & 8 & 9 \\
\hline Azimuth (A) & Dip (D) & Sine A & $\operatorname{Cos} \mathrm{A}$ & Cos D & $\begin{array}{l}5 \times 4 \\
\text { b }\end{array}$ & $\begin{array}{l}5 \times 3 \\
a\end{array}$ & $\begin{array}{l}\text { Sine D } \\
\text { C }\end{array}$ & $\left(A_{I}-A\right)^{2}$ \\
\hline 100 & 20 & 0.9848 & -0.1736 & 0.9397 & -0.1631 & 0.9254 & 0.3420 & 62.41 \\
\hline 68 & 22 & 0.9272 & 0.3746 & 0.9272 & 0.3473 & 0.8597 & 0.3746 & 580.81 \\
\hline 100 & 19 & 0.9848 & -0.1736 & 0.9455 & -0.1641 & 0.9311 & 0.3256 & 62.41 \\
\hline 98 & 24 & 0.9903 & -0.1392 & 0.9135 & -0.1272 & 0.9046 & 0.4067 & 34.81 \\
\hline 98 & 24 & 0.9903 & -0.1392 & 0.9135 & -0.1272 & 0.9046 & 0.4067 & 34.81 \\
\hline 88 & 16 & 0.9994 & 0.0349 & 0.9613 & 0.0335 & 0.9607 & 0.2756 & 16.81 \\
\hline 80 & 14 & 0.9848 & 0.1736 & 0.9703 & 0.1684 & 0.9556 & 0.2419 & 146.41 \\
\hline 94 & 12 & 0.9976 & -0.0698 & 0.9781 & -0.0683 & 0.9758 & 0.2079 & 3.61 \\
\hline 88 & 14 & 0.9994 & 0.0349 & 0.9703 & 0.0339 & 0.9697 & 0.2419 & 16.81 \\
\hline 104 & 18 & 0.9703 & -0.2419 & 0.9511 & -0.2301 & 0.9229 & 0.3090 & 141.61 \\
\hline 96 & 18 & 0.9945 & -0.1045 & 0.9511 & -0.0994 & 0.9459 & 0.3090 & 15.21 \\
\hline 100 & 20 & 0.9848 & -0.1736 & 0.9397 & -0.1631 & 0.9254 & 0.3420 & 62.41 \\
\hline 64 & 22 & 0.8988 & 0.4384 & 0.9272 & 0.4065 & 0.8334 & 0.3746 & 789.61 \\
\hline 110 & 22 & 0.9397 & -0.3420 & 0.9272 & -0.3171 & 0.8713 & 0.3746 & 320.41 \\
\hline Total & & 13.6467 & -0.501 & 13.2157 & -0.47 & 12.8861 & 4.5321 & 2288.14 \\
\hline$(\text { Total })^{2}$ & & 186.232 & 0.251 & 174.654 & 0.221 & 166.051 & 20.539 & $5.23^{*} 10^{\wedge} 6$ \\
\hline
\end{tabular}

Table 3c: Paleocurrent Parameters for Crossbed 2

\begin{tabular}{|l|l|l|l|l|l|l|l|l|}
\hline 1 & 2 & 3 & 4 & 5 & 6 & 7 & 8 & 9 \\
\hline $\begin{array}{l}\text { Azimuth } \\
(\mathrm{A})\end{array}$ & $\begin{array}{l}\text { Dip } \\
(\mathrm{D})\end{array}$ & Sine A & Cos A & Cos D & $\begin{array}{l}5 \times 4 \\
\text { b }\end{array}$ & $\begin{array}{l}5 \times 3 \\
\text { A }\end{array}$ & $\begin{array}{l}\text { Sine D } \\
\text { C }\end{array}$ & $\left(\mathrm{A}_{\mathbf{I}}-\mathrm{A}\right)^{2}$ \\
\hline 78 & 20 & 0.9781 & 0.2079 & 0.9397 & 0.1954 & 0.9191 & 0.3420 & 3.8416 \\
\hline 70 & 24 & 0.9397 & 0.3420 & 0.9397 & 0.3214 & 0.8830 & 0.4067 & 99.20 \\
\hline 56 & 22 & 0.8290 & 0.5592 & 0.8470 & 0.4736 & 0.7022 & 0.3746 & 574.08 \\
\hline 62 & 24 & 0.8829 & 0.4695 & 0.9135 & 0.4289 & 0.8065 & 0.4067 & 322.56 \\
\hline 84 & 30 & 0.9903 & 0.1392 & 0.8660 & 0.1205 & 0.8576 & 0.5 & 16.32 \\
\hline 74 & 28 & 0.9613 & 0.2756 & 0.8829 & 0.2433 & 0.8487 & 0.4695 & 35.52 \\
\hline 73 & 28 & 0.9563 & 0.2924 & 0.8829 & 0.2582 & 0.8443 & 0.4695 & 48.44 \\
\hline 108 & 30 & 0.9511 & -0.3090 & 0.8660 & -0.2676 & 0.8236 & 0.5 & 786.24 \\
\hline 63 & 30 & 0.8910 & 0.4540 & 0.8660 & 0.3932 & 0.7716 & 0.5 & 287.64 \\
\hline 100 & 20 & 0.9848 & -0.1736 & 0.9397 & -0.1631 & 0.9254 & 0.3420 & 401.60 \\
\hline 98 & 16 & 0.9903 & -0.1392 & 0.9613 & -0.1338 & 0.9520 & 0.2756 & 325.44 \\
\hline 80 & 18 & 0.9848 & 0.1736 & 0.9511 & 0.1651 & 0.9366 & 0.3090 & 0.016 \\
\hline 90 & 26 & 1 & 0 & 0.8988 & 0 & 0.8988 & 0.4384 & 100.80 \\
\hline 88 & 18 & 0.9994 & 0.0349 & 0.9511 & 0.0332 & 0.9505 & 0.3090 & 64.64 \\
\hline 78 & 19 & 0.9781 & 0.2079 & 0.9455 & 0.1966 & 0.9248 & 0.3256 & 3.84 \\
\hline Totals & & 14.3171 & 2.5344 & 13.6512 & 2.2649 & 13.0448 & 2.2649 & $3.1 * 10^{\wedge} 3$ \\
\hline${\text { (Total })^{2}}^{2}$ & & 204.98 & 6.423 & 186.36 & 5.1297 & 170.167 & 5.1297 & $9.4 * 10^{\wedge} 6$ \\
\hline
\end{tabular}

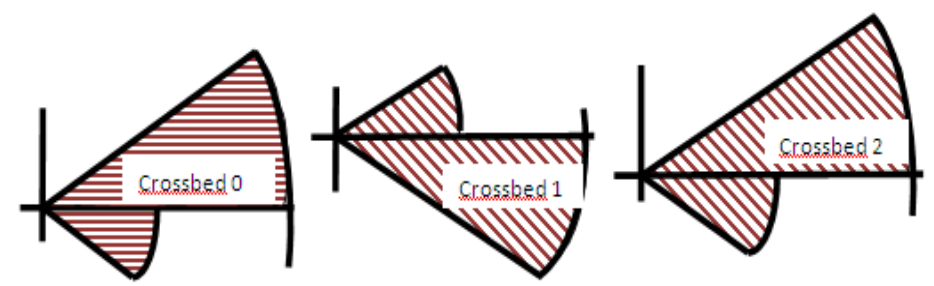

Fig 3: Rose diagram for Ogbunike sandstone 
Sedimentology and Sequence Stratigraphy of the Eocene Nanka Formation (Ameki Group): ...

Table 3d: Paleocurrent Results for the Nanka Formation(Ogbunike) and their Environment implication

\begin{tabular}{|l|l|l|l|l|l|l|l|}
\hline Locality & Outcrop & Lithostratigraphic Unit & Pattern & MVA & Variance & $\begin{array}{l}\text { Vector } \\
\text { Strength }\end{array}$ & $\begin{array}{l}\text { Environmental } \\
\text { implication }\end{array}$ \\
\hline Ogbunike & Crossbed 0 & Nanka Formation & Unimodal & $260.39^{\circ}$ & $265.04^{\circ}$ & $13.914^{\circ}$ & Fluvial \\
\hline Ogbunike & Crossbed 1 & Nanka Formation & Unimodal & $272.10^{\circ}$ & $176.00^{\circ}$ & $13.32^{\circ}$ & Fluvial \\
\hline Ogbunike & Crossbed 2 & Nanka Formation & Unimodal & $259.96^{\circ}$ & $219.31^{\circ}$ & $14.09^{\circ}$ & Fluvial \\
\hline
\end{tabular}

The sieve analysis was carried out based on Folk and Wards, 1957 model. The univariate results as obtained from the sieve analysis carried out on samples 12, 19, crossbed o,crossbed 1 and crossbed 2 shows a mean size that is basically medium grained which suggests moderately energy of deposition. It is basically moderately sorted, positively skewed which is an indication that the distribution has fine material, with kurtosis that is basically mesokurtic.

The bivariate results if plotted as obtained from the sieve analysis (mean size vs. standard deviation; skewness vs. sorting) will indicate a fluvial dominated environment. See tables 4 and 5.

Table 4: Summary of Univariate Result

\begin{tabular}{|l|l|l|l|l|}
\hline Sample No. & Mean (ME) & Standard deviation (Sd) & Skewness (ski) & Kurtosis (KG) \\
\hline Unit 12 & 1.03 Medium Grained & 1.15 Poorly Sorted & 0.16 Positively Skewed & 0.91 Mesokurtic \\
\hline Unit 19 & 1.07 Medium Grained & 0.78 Moderately Sorted & 0.11 Positively Skewed & 0.98 Mesokurtic \\
\hline Cross bed zero (0) & 1.65 Medium Grained & 0.82 Moderately Sorted & 0.27 Positively Skewed & 0.93 Mesokurtic \\
\hline Cross bed one (1) & 1.65 Medium Grained & 0.81 Moderately Sorted & 0.27 Positively Skewed & 1.06 Mesokurtic \\
\hline Cross bed two (2) & 1.35 Medium Grained & 0.64 Moderately Sorted & 0.21 Positively Skewed & 1.17 Leptokurtic \\
\hline
\end{tabular}

Table 5: Summary of Bivariate Result

\begin{tabular}{|l|l|l|l|l|l|}
\hline Sample Number & $\mathrm{Mz}$ & 6 & Ski & MzVs 6 & Ski Vs 6 \\
\hline Unit 12 & 1.03 & 1.15 & 0.16 & Fluvial & Fluvial \\
\hline Unit 19 & 1.07 & 0.78 & 0.11 & Fluvial & Fluvial \\
\hline Cross bed 0 & 1.65 & 0.82 & 0.27 & Fluvial & Fluvial \\
\hline Cross bed 1 & 1.39 & 0.81 & 0.27 & Fluvial & Fluvial \\
\hline Cross bed 2 & 1.35 & 0.64 & 0.21 & Fluvial & Fluvial \\
\hline
\end{tabular}

SANDSTONE/SILTSTONE FACIES(C) The lithology of facies C exhibits clayey sand dominated units with siltstone. The siltstone are pinkish-brown, while the sandstone are brownish white, fine to medium grained moderately sorted with lenses of clay. They do not exhibit any noticeable sedimentary structure, but are moderately bioturbated.

\section{INTERSTRATIFIED CALCAREOUS CLAY AND SHALE FACIES (D)}

The interstratified calcareous clay and shale facies are white to pinkish brown, with various degrees of weathering and ferruginization. The shale issub fissile to fissile with interbedded calcareous clay, with thin lensoid. The top unit is medium to coarse, poorly sortedferruginous sandstone. These beds are laminated with mm-scale,parallel to wavy lamination in some sections.

PALEOENVIRONEMNT-The palynological analysis carried out on the shale units in facie A of the studied area aided in paleoenvironment interpretation. The palynomorphs of environmental value encountered in some of the examined samples includemonoporitesannulatus, grass pollen, which indicates open vegetation as in reed swamp within the tropical rainforest, (Umeji, 2002). Proxapertitiescursus/operculatus, spinizonocolpitesechinatus and psilatricolporitescrassus are pollen of brackish water palms inhabiting similar environment as that of mangrove swamp, (Umeji, 2002, Umeji and Nwajide, 2013).Schizosporisparvus is a fresh water alga, which inhabited fresh water swamp environment.Homotryblium spp.,is a typical of warm masses of lowerlatitudes (william and Bujak, 1977), and has also been related to near-shore and reduced conditions (Dybkjaer, 2004). The occurrence of Achilleodiniumbiformoides and the presence of species such as Homotryblium sp.,cordosphaeridium sp. and Diphysescolligerum in unit 23, indicate restricted neritic to outer neritic (continental shelf) depositional environment, with maximum depth range less than 200m, (van mourik and Brinkhuis, 2001) see table 4. 
Sedimentology and Sequence Stratigraphy of the Eocene Nanka Formation (Ameki Group): ...

Table 6: Summary of the palynomorphs \% frequency distribution and their paleoenvironmental inferences

\begin{tabular}{|l|l|l|l|l|l|}
\hline SAMPLE NO. & \multicolumn{2}{|l|}{ PALYNOMORPHS \% FREQUENCY } & $\begin{array}{l}\text { PALEO- } \\
\text { SALINITY }\end{array}$ & PALEOENVIRONMENTS \\
\hline & Spores & Pollen & Marine Species & & \\
\hline UNIT 21 & $44 \%$ & $56 \%$ & $0 \%$ & Fresh water & $\begin{array}{l}\text { Non-marine/Continental } \\
\text { Upper deltaic plain }\end{array}$ \\
\hline UNIT 23 & $42 \%$ & $50 \%$ & $8 \%$ & Brackishwater & $\begin{array}{l}\text { Marginal marine } \\
\text { Probably (estuarine or lagoon) }\end{array}$ \\
\hline UNIT 25 & $48 \%$ & $52 \%$ & $0 \%$ & Fresh water & $\begin{array}{l}\text { Non-marine/Continental } \\
\text { Upper deltaic plain }\end{array}$ \\
\hline UNIT 28 & $55 \%$ & $45 \%$ & $0 \%$ & Fresh water & $\begin{array}{l}\text { Non-marine/Continental } \\
\text { Upper deltaic plain }\end{array}$ \\
\hline
\end{tabular}

\section{Age Determination-}

Based on the stratigraphically important palynomorphs recovered from units 21, 23, 25 and 28 in facies A of the outcrop studied, middle Eocene was assigned to the area based on the following recovered age diagnosing index palynomorphs species such as monoporitesannulatus, Retibrevitricolpitestriangulatus, Retitricolporitesirregulari, Retistephanocolpiteswillamsi, ctenolophoniditescostatus, spinizonocolpitesechinatus, psilatricoploritescrassus, psilatricolporitesoperculatus, proxaperitescursus, striatopollisctatumbus, and Bombacidites sp. (Van Hoeken- Klinkenberg, 1996: Germereraad et al. 1968). This assemblage corresponds to the middle Eocene pantropicalmonoporitesannulatus zone of Germeraad et al (1968).

However, the presence of dinoflegellage cysts species, Achilleodiniumbiformoides in sample from unit 23, confirmed the above assigned age, (Eaton, 1976).

\section{Sequence Stratigraphic Interpretation}

The interpretation of sequence stratigraphy of the studied outcrop is based on vertical relationship of lithofacies, microfossil, palynology and stratigraphic model as adopted from Van-Wagoner et al., 1988.see fig 4 Dinoglagellatescrsts assemblages have proved to be useful in sequence stratigraphic model where they are abundant and diverse (Onuigbo et al, 2012).

The outcrop of the studied area was analyzed in terms of their main systems tracts, sequence boundaries, maximumflooding surfaces and stacking patterns.Highstand systems tract, which is a progradational deposits that form when sediment accumulation rate exceed the rate of increase in accommodation space was identified. Consequently, its depositional trends and stacking pattern are dominated by a combination of aggradation/progradation processes of sandstone/ironstone and shale. It is believed that thehighstand system tract is bounded it the base by amaximum flooding surface, which may be located within AmekiFormation.The frequent sandstone occurrence in the studied area may be linked to preferential fluvialincision during the subsequent stage of base level fall, as the forefront of the high stand wedge, which inherits the slope gradient of the shoreface or delta front environment, is commonly steeper than the fluvial equilibrium profile. catuneanu(2006),saucier (1974), Leopold and Boll (1979), Rashmani (1988), Blum (1991),Posamentier et al(1992), Allen and Posamentier(1994), Ainsworth and Walker (1994).

The High stand systems tract of the studied area showed an upward-fining sequence that continued the overall upward-decrees in grain size. The system tract which is a late high standsystem tract is defined by much lower rate of base level rise, which results in a stacking pattern (progadational components) that may be prone to channel clustering (Catuneanu 2006), toward the end of the High stand system tract was a forced regressive phase (forced regression) which is defined by Catuneanu(2002) as occurring during stage of base level fall, when the shoreline is forced to regress by the falling base level irrespective of the sediment supply. The low magnitude fall in base level which is always the case in a fluvial dominated environment gave rise to the high preservation potential of bivalvecoquina in the studied area.This suggest that the nature of scouring vs.aggradation processes is low and the angle of repose of clinoform (>1) is steeper and the fall in base level does not trigger scouring, and the forced regressionshoreface deposits are gradationally based (Catuneanu 2006). Sequence boundary which is a product of a fall in sea level that erodes the sub aerially exposed sediment surface capped the High stand system tract and the eroding surface of the down stepping sediments accompanying forced regression in the studied area. The sequence boundary was overland by the low stand systems tract in the studied area, which is sedimentary deposits accumulated during the stage of early-rise normal regression (Hunt and Tucker, 1992), is bounded by the sub aerial unconformity and it correlative conformity at the base and by the maximum regressive surface at the top. The depositional processes and stacking pattern as noted in the studied area are dominated by low-rate aggradations and progradation (Catuneanu, 2006). The area showed a coarsing upward sequence, with poor preservation potential and issusceptible to erosion. 


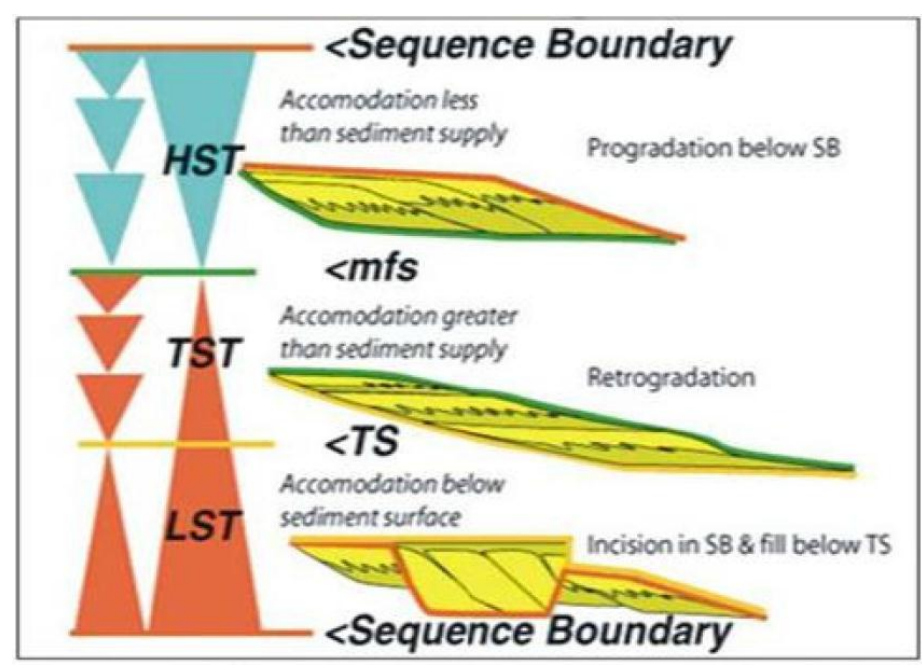

Fig 4: Sequence stratigraphic model (after Van Wagoner et al., 1988)

\section{Conclusion}

The Eocene Nanka Formation situated at a reference locality in Ogbunike south-eastern Nigeria shows a fluvial dominated environment,based on the paleocurrent and sieve analyses results.The age-diagnosting index- palynomorphs species recovered from shale units in Facies A suggest a middle Eocene age for the studied section;while paleoenvironmental result as revealed by the palynological analyses suggest an environment within a continental shelf.The sequence stratigraphic model indicated the presence of one type II sequence boundary,with a late highstand systems tract associated with forced regression and lowstand systems tract

\section{References}

[1]. Ainsworth, R. B. Walker, R. G. (1994).Control of estuarine valley-fill deposition by Fluctuation of relative Sea-level, Cretaceous Bearpaw-Horseshoe Canyon transition, Drumheller, Alberta, Canada. In Incised-valley systems: Origin and Sedimentary Sequences (R. G. Dalrymple R. Boryd, and B. A. Zaitlin, Eds) pp. 159-174. SEMP (Society of sedimentary Geology) Special publication No. 51

[2]. Allen, G. P., and Posamentier, H. W. (1994).TransgressiveFacies and Sequence architecture in mixed tide and wave dominated incised Valleys: example from the Gironde Estuary, France. In Incised valley systems: Origin and sedimentary sequences (R. W. Dalrymple, R. Boyd and B. A. Zaitlin, Eds) SEMP Special Publication 51, pp. 225-240.

[3]. Benkhelil, J., 1989. The Origin and Evolution of the Cretaceous Benue Trough of Nigeria: Journal of Africa Earth Science, V. $8,251-282$

[4]. Blom, M. D. (1991) Systematic Controls of genesis and architecture of allorialsequences: a late Quaternary example. In NUNA Conference on High-Resolution Sequence Stratigraphy (D. A. Leckie, H. W. Posamentier and R. W. Lovell Eds.) pp. 7-8. Program with Abstracts

[5]. Boggs,S., 2006. Principles of Sedimentary and Stratigraphy.Pearson Education, inc. Fourth edition. P. 114-115.

[6]. Catuneanu, O, (2006) Principles of Sequence Stratigraphy. Elsevier.Pp 105-222.

[7]. Catuneanu, O. (2002). Sequence Stratigraphy of Clastic systems: Concepts, merits and pitfalls.Journal of African Earth sciences, vol. 35/1, pp. 1-43

[8]. Chiaghanam, O.I. 2008.Lithofacies and Paleoenvironment of the Eocene Sediments of Umunya in Anambra State, Nigeria. Natural and Applied Sciences Journal, vol. 9, No. 2, 217-229.

[9]. Dybkjr, K., 2004. Morphological and abundance variations in Homotryblium-cyst assemblages related to depositional environments; uppermost Oligocene-Lower Miocene, Jylland, Denmark. Palaeogeogeography, Palaeoclimatology, Palaeoecology, 206: 41-58.

[10]. Eaton, G.L., 1976. Dinoflagenllate cysts from the Breaklesham beds (Eocene) of the Isle of Wight, Southern England. Bulletin of the British Museum (Natural History) 26: 227-332.

[11]. Folk, R.L. and Ward, W.C. 1957. Brazos River bar, a study in the significance of grain-size parameters: J. Sed. Petrology, 27, pp. 327.

[12]. Germeraad, J. H.,Hopping, C. A. and Muller, J., 1968.Palynology of Tertiary sediments from tropical areas.Review of Paleobotany. Palynology Vol. 6: pp 189-343.

[13]. Hunt, D., and Tucker, M. E. (1992) Stranded parasequences and the Forced regressive wedge systems tracts: deposition during base-level fall. Sedimentary Geology, Vol. 81, pp. 1-9.

[14]. Ibrahim, M. I. A., Abdul Ela, N. M. and Kholeif, S. E., 1997.Paleoecology, palynofacies, thermal maturation and hydrocarbon source-rock potential of the Jurassic-lower Cretaceous sequence in the subsurface of the north Eastern Desert, Egypt. Qatar University Science Journal, volume 17 (1), p. 153-172

[15]. Leopold, and Bull, W. B. (1979).Base level, aggradation, and grade.American Philosophical society, Proceedings, vol. 123, pp. 168202 .

[16]. Murat, R.C., 1972. Stratigraphy and Paleogeography of the Cretaceous and Lower tertiary in southern Nigeria. In Dessavuagie, T.F.J. and whiteman, A.J., (Eds), African Geology . University of Ibadan press, p.251-266.

[17]. Nwachukwu, U.E.D, Anyiam, O.A., Egbu, O.C. and Obi, I.S., 2011. Sedimentary controls on the reservoir properties of the paleogenefluvio-tidal sands of the Anambra Basin, Southeastern Nigeria-implication for deepwater reservoir studios. American journal of scientific and industrial research.Vol. 2(1).37-48. 
Sedimentology and Sequence Stratigraphy of the Eocene Nanka Formation (Ameki Group): ...

[18]. Nwajide, C.S. and Reijers,T.J.A., 1996. Sequence Architecture in outcrops: examples from the Anambra Basin.NAPE Bull., V. 11, p.23-32.

[19]. Nwajide, C.S., 1979. A Lithostratigraphic analysis of the Nanka Sand, Southeastern Nigeria.Nigeria Journal of Mining and Geology, V .16, P.103- 109 .

[20]. Nwajide, C.S., 1980. Eocene tidal sedimentation in the Anambra Basin, Southern Nigeria.Sedimentary Geol., v.25.P.189-207.

[21]. Nwajide, C.S., 2006. Outcrop analogies as a learning facility for subsurface practitioners: the value of geology field trips. Petroleum training journal ,v.3, p.58-68

[22]. Nwajide, C.S., 2013. Geology of Nigeria's sedimentary basins.CSS Bookshops.347-518.

[23]. Obi, G.C., Okogbue, C.O. and Nwajide, C.S., 2001. Evolution of the Enugu coeta: A tectonically driven erosion process: Global Journal of pore and applied sciences, vol.7, 321-330.

[24]. Oboh-Ikuenobe, F.E., Obi, G.C. and Jaramillo, C.A., 2005.Lithofacies, Palynofacies and Sequence Stratigraphy of Palaeogene strata in Southeastern Nigeria: journal of 02sciences, Vol. 41, 75-100.

[25]. Onuigbo, E. N., Efu-Efeotor J.O and Okoro A. V.,Palynogy, Paleoevironment and sequence stratigraphy of the Campanian Maastrichtian Deposits. The Anambra Basin, Southeastern Nigeria.European Journal of Scientific Research. Vol. 78 No.3, pp. 333348

[26]. Posamentier, H. W., Allen, G. P. James, D. P., and Tesson, M. (1992) Forced regressions in a Sequence Stratigraphic Framework: Concepts, examples, and exploration significance. American Association of Petroleum Geologists Bulletin, vol.76, pp. 1687-1709.

[27]. Rahmani, R. A. (1988). Estuarine tidal channel and near shore sedimentary of a late Cretaceous epicontinental sea, Drumheller, Alberfa, Canada. In Tide-influenced sedimentary Environments and facies (p.l. de Boer, A. van Gelder and S. D. No.Eds), pp. 433471.

[28]. Reyment, R.A., 1965. Aspects of the geology of Nigeria: the stratigraphy of the Cretaceous and Cenozoic Deposits. Ibadan University Press, 145p.

[29]. Sauicer, R. T. (1974). Quaternary Geology of the Lower Mississippi Valley.Arkaness Archeological survey, Research series No. 6, p. 26.

[30]. Steinmetz, R. 1962. Analysis of Vectorial Data. J. Sed. Petrology, 32, 801-812.

[31]. Umeji, O. P. and Nwajide, C. S. 2013. Record of warm temperate pollen from the Palaeogene -Neogene lignite of southeast Nigeria: Consequences of regional palaeoclimatic changes or tectonics? Quaternary International.Pp.43 - 47.

[32]. Umeji, O. P., 2002. Mid-Tertiary Late Eocene - Early Miocene age of lignites from Mpu Formation of Abakaliki Basin, Southeastern Nigeria. Journal Mining and Geology, Volume 38 (2), pp 11

[33]. Umeji, O.P., 2003. Palynological data from the road section at the Ogbunike toll gate, Onitsha, Southern Nigeria. Journal of Mining and Geol., V. 39, P. 95-102.

[34]. Van Hoeken-Klinkenberg, P. M. J., 1966. Maastrichitian, Paleocene Eocene pollen and spores from Nigeria.Leidse. Geol. Meded., $38: 37-48$

[35]. Van Mourik, C. A. and Brinkhuis, H., 2001.Middle to Late Eocene organic-walled dinoflagellate cysts from ODP leg 17IB, offshore Froride. In: Kroon. D., Norris, R. D. and Klaus, A., (Edition), western North Atlantic Paleogene and Cretaceous Palaeocenography. Geological Society Special Publication, 101:225-251.

[36]. Van Wagoner, J. C., H. W. Posamentier, R. M. Mitchum, P. R. Vail, J. F. Sarg, T. S. Loutit and J. Hardenbol, 1988. An overview of sequence Stratigraphy and key definitions. In: C. W., Wilgus et al, (Eds.) Sea level changes: an integrated approach: Society of Economic Paleontologists and Mineralogists special Publication 42, pp: 39-45

[37]. Williams, G. L. and Bujak, J. P., 1977a. Cenozoic Palynostratigraphy of offshore Eastern Canada. American Association of StratitgraphicPalynologists Foundation, Contribution Series 5A, 13-65. 